\title{
Organisational Resource Capacity and ISO 9001 QMS Implementation in the Local Government. Evidence from Poland
}

\author{
Marek Ćwiklicki ${ }^{1}$ (D) Barbara Pawełek $^{2}$ (D) Kamila Pilch $^{1}$ (D) \\ Published online: 8 September 2020 \\ (C) The Author(s) 2020
}

\begin{abstract}
The aim of the paper is to answer the research question regarding the relations between the resources that are related to organisational capacity and the implementation of the ISO 9001 QMS in local governments. In the case of poviats (counties), the significance of the resources under consideration for the implementation of the ISO 9001 QMS has not been confirmed. On the other hand, the significance of the selected indicators appeared in the case of gminas (municipalities), including human resources, skills, money and the complexity of the structure. The differences in the importance of the resources under consideration in the case of dividing gminas into urban, rural and urban-rural (semi-urban) gminas was also observed. Our theory-testing research work weakens the common assumptions about the significance of resource availability, as not all are equally important.
\end{abstract}

Keywords Organisational capacity · ISO 9001 QMS · Local government · Poland

\section{Introduction}

In all current public administration paradigms, the quest for efficiency and effectiveness is formulated. To meet the target values for key performance indicators, researchers

Marek Ćwiklicki

marek.cwiklicki@uek.krakow.pl

Barbara Pawełek

barbara.pawelek@uek.krakow.pl

Kamila Pilch

kamila.pilch@uek.krakow.pl

1 Department of Management of Public Organisations, Cracow University of Economics, ul. Rakowicka 27, 31-510 Cracow, Poland

2 Department of Statistics, Cracow University of Economics, Rakowicka 27, 31-510 Cracow, Poland 
recommend using a proper management framework, system, or style, which would enable one to deal with complex public affairs. Among these approaches is the ISO 9001 Quality Management System (ISO 9001 QMS), which is one of the most recognised systems with indicated utility in private businesses. Scholars have noticed that pursuing new solutions requires resources such as money and people, which are in the case of public administration - limited. The notion regarding the organisational resource capacity (or, in short, organisational capacity) is especially crucial for local governments that possess fewer resources than the regional and national public administration bodies. This matter is especially important for public administrations in developing economies. Therefore, this issue will be illustrated using the example of Polish local government units (LGUs). The aim of the paper is to answer the research question about the relations between the resources that are related to the organisational capacity and implementation of the ISO 9001 QMS in local governments.

\section{Literature Review}

\section{Resources and QMS ISO 9001 Implementation and Maintenance}

Introducing QMS ISO 9001 requires some effort and resources. The list of resources that is related to the implementation and maintenance of ISO 9001 certification contains, among other, the following: consultant fees, certification fees, equipment calibration fees, the costs of purchasing additional equipment, the costs of establishing the documentation system, staff training, and additional time spent on setting up and maintaining the ISO 9001 system (Leung et al. 1999). However, the significance of the factors supporting the ISO 9001 implementation can differ among different business sectors (Almeida et al. 2018). Moreover, even companies from the same industry differently assess the significance of obstacles to ISO 9001 certification (Sfakianaki and Kakouris 2018). Previous studies showed that the barriers to the implementation and maintenance of the ISO 9001 QMS are related to the high costs of resources (Sampaio et al. 2009). Therefore, resources are necessary but not sufficient for the successful introduction of this kind of solution to organisations.

Public administration organisations are not inclined to implement such solutions due to the additional expenditures. Nevertheless, the search for new and better management methods in public administration is forced by internal constraints (e.g., budget deficits) and external constraints (e.g., pressures from plurilateral public procurement) in the light of limited resources (Saner 2002). Moreover, studies show the positive impacts of QMS on the performance of public local administrations (Chiarini 2016; Montesinos and Brusca 2009).

Since attention has been given to local governments, which constitute small and medium institutions (except big cities) with smaller budgets, it is convenient to refer to the relations between the demand for resources and small and medium-sized organisations. A previous study among companies showed that there was a correlation between the costs of additional staff in the abovementioned phases and audit fees (Leung et al. 1999). Further analysis showed that in SMEs, successful implementation is related to the internationalisation of QMS into daily practice (Briscoe et al. 2005). The last study emphasises the role of the intangible resources that are required in ISO 9001 
implementation. However, Psomas et al. (2010) showed that the critical success factors (i.e., those that are needed for effective implementation), except for resource constraints, include the following: the internal motivation of the organisation, the attributes of the organisation (e.g., size and infrastructure), the attributes of the employees (e.g., training and numbers), the requirements of the quality system (e.g., financial resources and paperwork), and the attributes of the external environment (e.g., pressure from competitors and customers). Studies on the obstacles to ISO 9001 certification revealed that SMEs in the Greek food and beverage industry counted the following factors as barriers: the bureaucracy, the lack of support from the top management, time and resources constraints, and employees' attitudes (Sfakianaki and Kakouris 2018). From the review of previous studies, diverse sets of factors that are related to the implementation and maintenance of the ISO 9001 QMS, including tangible and intangible resources, was observed.

The presented list of resources determines the organisational resource capacity in private companies. Our intention is to examine public administrations where the type of activity and desire to economise activities restrict access to the main resources that are needed to implement and maintain quality standards. A study on public organisations in Taiwan revealed that small units have the necessary entrepreneurial spirit and motivation to pursue new management concepts, but they struggle with weaker ISO 9001 QMS awareness and managerial capabilities (Chu and Wang 2001). Thus, large organisations benefit because of "the greater propensity of large public organisations to have more manpower and budget to deal with the more complex quality systems" (Chu et al. 2001, p. 408). The correlations between the size of organisations and the implementation of ISO 9001 QMS has been demonstrated by research from Poland (Ćwiklicki et al. 2019). According to another study on the implementation of ISO 9001 QMS in the public administration of Macao SAR, the system improves organisational performance but requires more resources and commitment (To et al. 2011). In the light of the conducted analyses, the studies on QMSs and local governments are few and incomplete in terms of the lack of cross-country comparisons.

\section{Organisational Resource Capacity}

Our research is focused on the organisational resource capacity (or, in short, organisational capacity). The capacity it defined as "the ability to marshal and use available resources - people, money, talent, and time - in the best possible way" (Ingraham 2005, p. 392). Another definition of organisational capacity that was proposed by J.J. Bos and R.R. Brown is "the implementation of innovative ideologies and practice" (Bos and Brown 2014, p. 2). However, Christensen and Gazley (2008) show that the capacity does not have an agreed-upon meaning among scholars, and it is a multi-dimensional concept. They pointed out different understandings of the capacity as a process, resources, or organisations' qualities. The capacity can be viewed from both macro- and micro levels and it cannot be directly observed (Tan 2019). Christensen and Gazley stretch its coverage outside organisations to include the external environment (e.g., government structure, relationships, etc.) (Christensen and Gazley 2008, p. 268). The other dimensions are as follows: human resources, infrastructure and financial. The most comprehensive definition of the capacity was proposed by E. Tan who stated that it is just the "ability to perform" (Tan 2019, p. 52), 
although he provides more detailed explanations about the scope of the definition. In addition to the above meaning, organisational capacity is the equivalent of "management capacity" (Björk et al. 2014). Additionally, a similar definition of the organisational capacity for change is the "abroad and dynamic organisational capability that allows the enterprise to adapt old capabilities to new threats and opportunities as well as create new capabilities" (Judge and Elenkov 2005, p. 894). Although the issue of tangible and intangible resources appears in this definition, the main focus is on dynamic capabilities and abilities. Similarly, M. McGuire and Ch. Silvia characterise the administrative capacity as "the skills and abilities (...) of the manager and the organisation" (McGuire and Silvia 2010, p. 281). Considering this definition, the capacity is understood as the potential and ability to do something that is not clearly indicated.

From the conducted literature review on the organisational resource capacity, the dominance of the resource-based view was observed. Our query on its meaning leads to the conclusion that the terminology is not homogenous. Its divergent nature and tangible and intangible aspects were noticed; therefore, four types of capabilities and their constituents as appropriate measures were chosen. These parameters are described in the "Materials and Methods" section.

\section{Materials and Methods}

Our materials include data about the number of ISO 9001 QMS implementations in local governmental units (poviats and gminas) in Poland and come from a survey that was conducted in 2015 among all 2478 municipalities (gminy) and 314 districts (powiaty). A total of 2150 LGUs' representatives responded to the survey on behalf of 1914 municipalities and 236 districts, having a high rate of response at $77 \%$.

The survey was carried out in the fourth quarter of 2015 under a project entitled 'Systemic Support for Management Processes in LGIs', which was implemented by a partnership that was composed of the following participants: the Ministry of Administration and Digitisation (leader), the University of Lodz, the University of Warmia and Mazury in Olsztyn, and the Małopolska School of Public Administration of the Cracow University of Economics. Supplementary data from a Polish Local Data Bank was obtained.

During the analysis, first, the relationship between the components of organisational capacity was explored. Second, the relationship between LGUs that have implemented the ISO 9001 QMS and those that have not was captured. Distinction between three types of gminas (rural, urban, and rural-urban (semi-urban or mixed)) and poviats was made. The typology is built using the agricultural scale of the gmina, which is commonly accepted in official statistics (OECD 2018, p. 115).

Based on the literature review, the following components as being part of the organisational capacity have been specified:

- human resources (number of employees per 10,000 inhabitants),

- skills (share of employees with higher education with respect to the total number of employees, and share of employees in managerial positions with respect to the total number of employees), 
- money (income per inhabitant, expenditures per inhabitant, and share of investment expenditures), and

- the complexity of the structure (local government's organisational units per 10,000 inhabitants).

Based on the literature review, the following hypotheses are formulated:

- H1. Resource availability is a condition sine qua non for the implementation of the ISO 9001 QMS in local government units.

- H2. Human resources and skills are the factors that will determinate the willingness to use the ISO 9001 QMS in the future.

- H3. Money is the most important factor differentiating all LGUs that have experience using the ISO 9001 QMS from those that do not have the experience.

- H4. Rural gminas will more often use financial assistance to implement the ISO 9001 QMS than other types of LGUs.

- H5. The complexity of the structure will be a determining factor in the ISO 9001 QMS implementation in urban gminas and poviats.

To verify the hypotheses, statistical analyses have been carried out for individual factors. The applied statistical procedures included a statistical description of the local government units belonging to both groups (gminas and poviats) and testing the statistical significance of the differences in the components that were selected for the analysis. The non-parametric Mann-Whitney U test and the Kruskal-Wallis test were used because the distribution of the data did not meet the assumptions for parametric tests. STATISTICA software to compute the values was used.

442 LGIs $(20,6 \%)$ declared that they use the ISO 9001 QMS or have done so in the past.

\section{Findings}

\section{Human Resources}

The index that was adopted for describing human resources is the number of employees per 10,000 inhabitants. Figure 1 allows us to compare the three groups of gminas (urban, rural, and urban-rural) and poviats. There is a difference in the median between the poviats (both those who have experience in the use of the ISO 9001 QMS and those that did not) and the different types of gminas. Diverse results among rural gminas who did not implement the ISO 9001 QMS are observed.

The conducted analyses showed statistically significant differences only in relation to the different types of gminas. The number of employment differentiates the types of gminas (urban, rural and urban-rural) (Table 1).

Additionally, in urban gminas, the analysed factor was significantly different for those urban gminas that have implemented the ISO 9001 QMS and used external support during the implementation compared to those that did not make use of external assistance during implementation. In the case of poviats, number of employees was significantly different for those who have experience in using the solution and responded that their unit has the ability to independently implement the solution compared to those who do not have such a capacity. 


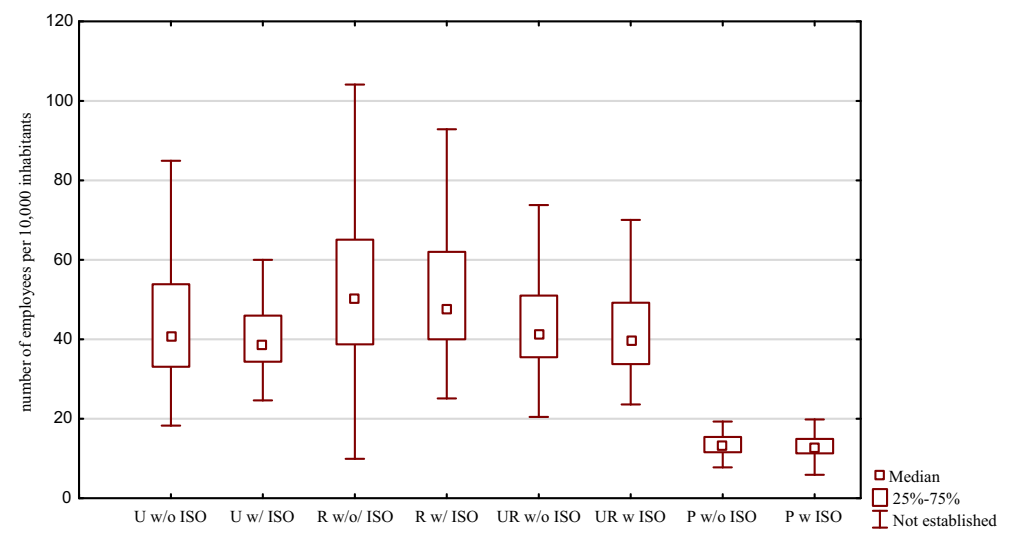

Key: U - urban gminas; R - rural gminas; UR - urban-rural gminas; P - poviats

Fig. 1 Box-plot - number of employees per 10,000 inhabitants in LGUs with and without the ISO 9001 QMS. Source: own elaboration

\section{Skills}

Two variables play important roles in the skills component: "share of employees with higher education with respect to the total number of employees" and "share of employees in managerial positions with respect to the total number of employees". Differences for the first role are statistically significant for the poviats, urban gminas and rural gminas that have implemented the ISO 9001 QMS and those that have not introduced the QMS (Table 2).

In the case of urban gminas, the number of employees with higher education differs in a statistically significant way for those LGUs who have experience with the ISO 9001 QMS and declare that they will use it in the future from those who do not plan to use the certified QMS in the future (at the significance level of $\alpha=0.1$ ).

The share of employees in managerial positions with respect to the total number of employees is different only for urban gminas that have implemented the ISO 9001 QMS and for those urban gminas that have not implemented it.

The obtained results allow us to positively verify hypothesis H2. Conclusion can be made that the number of employees with higher education is a factor differentiating only urban gminas that declare their willingness to use the QMS in the future.

Table 1 Multiple comparisons of the mean ranks of all pairs of groups ( $p$ value) - number of employees per 10,000 inhabitants in the three types of gminas

\begin{tabular}{llll}
\hline Type of gminas & urban & rural & urban-rural \\
\hline Urban & $\times$ & $<0.0005$ & $\geq 0.9995$ \\
Rural & $<0.0005$ & $\times$ & $<0.0005$ \\
urban-rural & $\geq 0.9995$ & $<0.0005$ & $\times$ \\
\hline
\end{tabular}

Kruskal-Wallis test: $H(2, N=1903)=114.7673$, and $p<0.0005$ 
Table 2 Share of employees with higher education with respect to the total number of employees relative to implementation of the ISO 9001 QMS

\begin{tabular}{lllllllllll}
\hline $\begin{array}{l}\text { LGUs } \\
\text { type }\end{array}$ & $\begin{array}{l}\text { Sum of } \\
\text { ranks w/o ISO }\end{array}$ & $\begin{array}{l}\text { Sum of } \\
\text { ranks w/ ISO }\end{array}$ & $U$ & $Z$ & $P$ & $\begin{array}{l}Z \\
\text { corrected }\end{array}$ & $p$ & $\begin{array}{l}N \text { w/o } \\
\text { ISO }\end{array}$ & $\begin{array}{l}N \text { w/ } \\
\text { ISO }\end{array}$ \\
\hline $\begin{array}{l}\text { poviats } \\
\text { urban }\end{array}$ & 14,745 & 12,283 & 5565 & -1.947 & 0.051 & -1.947 & 0.051 & 135 & 97 \\
gminas & 9449.5 & $12,705.5$ & 4298.5 & -2.740 & 0.006 & -2.740 & 0.006 & 101 & 109 \\
rural gminas & $688,005.5$ & $88,875.5$ & $64,719.5$ & -2.014 & 0.044 & -2.014 & 0.044 & 1116 & 130 \\
\hline
\end{tabular}

Mann-Whitney U test (with continuity correction)

The marked results are significant at the significance level of $\alpha=0.1$

\section{Money}

"Income per inhabitant", "expenditures per inhabitant" and "share of investment expenditures" are the factors related to the component money. In the case of urban gminas, both income and expenditures per inhabitant are variables that differentiate the analysed groups in a statistically significant way. These two indices differentiate LGUs that used the ISO 9001 QMS from those that did not. The share of investment expenditures differs in a statistically significant way only in the case of rural gminas (Table 3).

The diversity of both the income and expenditure per inhabitant variables are statistically significant for poviats and rural gminas with ISO 9001 QMS implementation that demonstrate their willingness to use the QMS in the future. The share of investment expenditures differs in a statistically significant way in the case of urban gminas that declared their willingness to use the QMS in the future (from those who do not intend to use it). In addition, this variable also differs in the same way in relation to having the ability to independently implement the ISO 9001 QMS. In case of urban-

Table 3 Mann-Whitney U test: factors related to money relative to the ISO 9001 QMS's implementation

\begin{tabular}{|c|c|c|c|c|c|c|c|c|c|}
\hline $\begin{array}{l}\text { Variable/type of } \\
\text { gminas }\end{array}$ & $\begin{array}{l}\text { Sum of } \\
\text { ranks w/o } \\
\text { ISO }\end{array}$ & $\begin{array}{l}\text { Sum of } \\
\text { ranks w/ } \\
\text { ISO }\end{array}$ & $U$ & $Z$ & $P$ & $\begin{array}{l}Z \\
\text { corrected }\end{array}$ & $p$ & $\begin{array}{l}N \text { w/o } \\
\text { ISO }\end{array}$ & $\begin{array}{l}N \mathrm{w} / \\
\mathrm{ISO}\end{array}$ \\
\hline $\begin{array}{l}\text { income per inhabitant } \\
\text { /urban }\end{array}$ & 9503 & 12,652 & 4352 & -2.618 & 0,009 & -2618 & 0,009 & 101 & 109 \\
\hline $\begin{array}{l}\text { expenditure per } \\
\text { inhabitant /urban }\end{array}$ & 9688 & 12,467 & 4537 & -2.198 & 0,028 & -2198 & 0,028 & 101 & 109 \\
\hline $\begin{array}{l}\text { income per inhabitant } \\
\text { /rural }\end{array}$ & $684,068.5$ & $92,812.5$ & $60,782.5$ & -3.028 & 0,002 & -3028 & 0,002 & 1116 & 130 \\
\hline $\begin{array}{l}\text { expenditure per } \\
\text { inhabitant /rural }\end{array}$ & $684,006.5$ & $92,874.5$ & $60,720.5$ & -3.044 & 0,002 & -3044 & 0,002 & 1116 & 130 \\
\hline $\begin{array}{c}\text { the share of investment } \\
\text { expenditure / rural }\end{array}$ & $688,830.5$ & $88,050.5$ & $65,544.5$ & -1.802 & 0,072 & -1802 & 0,072 & 1116 & 130 \\
\hline
\end{tabular}

Mann-Whitney U test (with continuity correction)

The marked results are significant at the significance level of $\alpha=0.1$ 
rural gminas, the share of investment expenditures is a variable that differs in a statistically significant way for those that used external support in the implementation of the standards compared to those who did not use the support.

The obtained results allow us to verify hypotheses $\mathrm{H} 3$ and H4. Thus, conclusion can be drawn that the variables that are related to money differentiate the analysed LGUs that have experience with the use of the ISO 9001 QMS from those that do not have experience as follows:

- income and expenditures are important differentiating factors only for urban and rural gminas, and

- the share of investment expenditures is an important differentiating factor only for rural gminas.

\section{Complexity of the Structure}

The local government's organisational units per 10,000 inhabitants is the index that was adopted to describe the complexity of the structure. This index differentiated only urban and urban-rural gminas who have experience with the application of the ISO 9001 QMS and those that did not use it (Table 4).

There is also a statistically significant relationship between the number of local government's organisational units per 10,000 inhabitants and the willingness to use the ISO 9001 QMS in the future in the case of urban gminas that have experience using the QMS. In that case, hypothesis H5 was confirmed. Only in the urban-rural gminas is there a statistically significant relationship between this variable and the ability to implement and/or use the QMS in the future. The complexity of the structure is an important variable for statistically significantly differentiating poviats that used the external support in the implementation of the solution and those that did not use the assistance.

\section{The ISO 9001 QMS in Polish Gminas: Support Type and Benefits}

Three hundred forty-six gminas that have experience in the application of the ISO 9001 QMS took part in the study. They were asked about the type of assistance that they used in their introduction of the QMS. The responders could choose several of the following types of assistance:

Table 4 Mann-Whitney U test for local government's organisational units per 10,000 inhabitants relative to the variable implemented ISO

\begin{tabular}{llllllllll}
\hline $\begin{array}{l}\text { Types of } \\
\text { gminas }\end{array}$ & $\begin{array}{l}\text { Sum of ranks } \\
\text { w/o ISO }\end{array}$ & $\begin{array}{l}\text { Sum of ranks } \\
\text { w/ ISO }\end{array}$ & $U$ & $Z$ & $P$ & $Z$ & $P$ & $\begin{array}{l}N \text { w/o } \\
\text { ISO }\end{array}$ & $N$ w/ ISO \\
\hline urban & 11,772 & 10,383 & 4388 & 2.537 & 0.011 & 2.537 & 0.011 & 101 & 109 \\
urban-rural & $79,354.5$ & $20,773.5$ & $14,995.5$ & 2.741 & 0.006 & 2.741 & 0.006 & 340 & 107 \\
\hline
\end{tabular}

Mann-Whitney U test (with continuity correction)

The marked results are significant at the significance level of $\alpha=0.1$ 
- information support,

- financial support,

- expert assistance, and

- consulting.

For the purpose of the analysis, a variable was created that contained a combination of particular types of support. This approach allowed us to assess the frequency of the joint use of particular types of support for different types of gminas. In the case of urban and urbanrural municipalities, the most frequently used types of support were expert assistance, information support and consultants. This result means that they have chosen non-tangible support. On the other hand, rural communes most often used every possible type of support during their implementation. Conclusion can not be made that their budgets often lack the financial resources that are needed to finance the implementation (Table 5).

It should be noted that the distinguished components of the organisational resource capacity have differentiated the scope of the aid that is used by individual gminas.

Respondents who implemented the ISO 9001 QMS were asked to indicate (maximum 3) the main benefits from the QMS that they implemented. An index to identify different achieved benefits has been developed. The response categories contained the following options:

- management improvement,

- provided services quality improvement,

- assessment of the unit's potential,

- problem identification,

- improvement of resource use, and

- improvement of the assessment of activities by residents.

In relation to all types of gminas, the most frequently indicated benefits were as follows: management improvement, services quality improvement, and problem identification. It is worth mentioning that $4-5 \%$ of all gminas do not see any benefits from implementing the ISO 9001 QMS (5\% in the case of urban and urban-rural gminas and $4 \%$ in the case of rural gminas). It seems reasonable to say that in the case of rural municipalities, the availability of financial resources is a factor that significantly limits the implementation of the QMS in LGUs (Table 6).

In addition, hypothesis $\mathrm{H} 4$ that rural gminas more frequently used financial assistance in the implementation of the ISO 9001 QMS than other LGUs was positively verified.

Table 5 Frequency of used support in implementing ISO 9001 QMS in Polish LGUs (\%)

\begin{tabular}{llll}
\hline Type of support: & \multicolumn{2}{l}{ Type of gminas } \\
\cline { 2 - 4 } & urban & rural & urban-rural \\
\hline expert assistance + information support + consulting + financial support & $13 \%$ & $\mathbf{3 6 \%}$ & $\mathbf{2 0 \%}$ \\
expert assistance + information support + consulting & $\mathbf{2 4 \%}$ & $\mathbf{1 6 \%}$ & $\mathbf{3 3 \%}$ \\
expert assistance + information support & $\mathbf{2 0 \%}$ & $8 \%$ & $8 \%$ \\
expert assistance & $13 \%$ & $3 \%$ & $11 \%$ \\
\hline
\end{tabular}




\section{ISO 9001 QMS in Polish Poviats: Support Type and Benefits}

Ninety-six poviats that have experience in the application of the ISO 9001 QMS took part in the study. As in the case of gminas, the goal was to assess what kind of assistance poviats used during their implementation of the QMS and what main benefits that they identify after its introduction. Table 7 shows that most often used support is the combination of information support, expert assistance and consulting activities in poviats $(25 \%)$. Next, was a combination of information support, financial support, expert assistance and consulting. Only $3 \%$ of respondents did not use any kind of support when implementing the solution (Table 7).

In case of poviats, with respect to those who using consulting, two characteristics, income per inhabitant and share of investment expenditures, differentiated the compared groups in a statistically significant way. For the other types of support that were by the poviats, there were no organisational capacity components that would differentiate them in a statistically significant way.

As in the case of poviats, the most often mentioned benefits of the ISO 9001 QMS implementation were quality improvements in management and services and enhanced problem identification. Next, improvement of the management, improvement of the provided services quality and improvement of the assessment of activities by residents were reported. Further, 3\% of all respondent did not see any benefits from the implementation of the ISO 9001 QMS. However, it is interesting that all types of LGUs (poviats and gminas) most often identified the same bundle of benefits (Table 8).

For those poviats that stated that the implementation of the ISO 9001 QMS brought management improvements, a statistically significant differentiating variable was the share of employees with higher education. In addition, for those poviats that stated that the implementation of the analysed solution allowed for the identification of problems, the share of employees in managerial positions with respect to the total number of employees differentiated the compared groups in a statistically significant way.

\section{Resources and Willingness to Abandon the ISO 9001 QMS}

Some respondents to the survey declared their willingness to abandon the ISO 9001 QMS. They had the opportunity to give their reasons for this. The question about the reasons for quitting the ISO 9001 QMS was an open question in the survey, and not all respondents gave an answer to this question. However, is it possible to see some patterns. The most frequently appearing comments and the connections between them are shown below (Fig. 2).

Table 6 Main indicated benefits in gminas (frequency in \%)

\begin{tabular}{llll}
\hline Type of benefit: & \multicolumn{2}{c}{ Type of gminas } \\
\cline { 2 - 4 } & urban & rural & urban-rural \\
\hline $\begin{array}{l}\text { improvement of management + improvement of } \\
\text { services quality + problem identification } \\
\begin{array}{c}\text { improvement of management + improvement of } \\
\text { services quality + improvement of the assessment of activities by residents }\end{array}\end{array}$ & $31 \%$ & $20 \%$ & $22 \%$ \\
\hline
\end{tabular}


Table 7 Often used support in poviats (frequency in\%)

\begin{tabular}{lc} 
Mix of support: & Frequency \\
\hline expert assistance + information support + consulting & $25 \%$ \\
expert assistance + information support + consulting + financial support & $22 \%$ \\
expert assistance + information support & $13 \%$ \\
expert assistance & $11 \%$
\end{tabular}

The ISO 9001 QMS is perceived as a very complex solution. Therefore, the lack of visible effects from using it and the high financial costs are the factors determining the lack of willingness to use it in the future. With respect to the capacity, the issue of available funds (financial resources) again appears as a determinant for implementing quality management systems in LGUs. Additionally, in the case of smaller LGUs, there is a shortage of personnel who could take part in implementing and monitoring the application of the ISO 9001 QMS. Human resources are related to the lack of financial resources. Another issue is the abandonment of the use of the certified QMS and the willingness to use alternative solutions. This could mean that other QMSs have more desirable functionalities or are less resourcedependent (e.g., the CAF does not require a certification fee).

The indicated reasons agree with the factors that have been highlighted as key components of the organisational capacity. It means that resource availability is a condition sine qua non for the implementation of the ISO 9001 QMS in LGUs. Particularly, in the opinion of the respondents who intend to quit using the QMS, it seems to be a valid statement that without having adequate resources (financial and human), even the implementation of the solution may not bring satisfactory results. This statement agrees with hypothesis H1. However, it should be emphasised that the obtained results should be considered (due to the small number of answers) as exploratory, and the generalisation of the conclusions should be preceded by further research in this area. More quantitative research would be needed to statistically verify this hypothesis and whether the observed regularities are statistically significant for all entities that have declared that they do not want to use the ISO 9001 QMS in the future.

\section{Results and Discussion}

As the final results of our analysis, the following hypotheses have been verified:

- H1. Resource availability is a condition sine qua non for the implementation of the ISO 9001 QMS in local government units - partially confirmed.

Table 8 Main benefits from implementing ISO 9001 QMS in poviats (frequency in \%) 


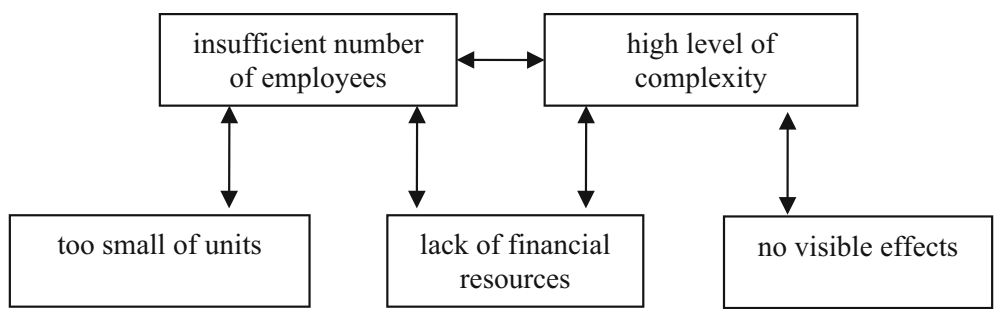

Fig. 2 Reasons for abandoning the ISO 9001 QMS. Source: own elaboration

- H2. Human resources and skills are the factors that will determinate the willingness to use the ISO 9001 QMS in the future - partially confirmed.

- H3. Money is the most important factor differentiating all territorial units that have experience in using the ISO 9001 QMS from those that do not have such experience - partially confirmed,

- H4. Rural gminas will more often use financial assistance to implement the ISO 9001 QMS than other types of territorial units - confirmed.

- H5. The complexity of the structure will be a determining factor in the ISO 9001 QMS implementation in urban gminas and poviats - partially confirmed.

Previous studies showed the indirect effects of financial resources on service performance via possessing real resources (i.e., mainly, the quantity and quality of staff) (Boyne 2003). Our findings support this observation. The analysis was focused on the different types of gminas and showed that the significance of resources varies across the different types. In the case of poviats, it has not been confirmed the significance of the resources under consideration for the implementation of the ISO 9001 QMS. On the other hand, in the case of gminas, the significance of the selected indicators concerning human resources, skills, money and the complexity of the structure was highlighted. The differences in the importance of the resources when dividing gminas into urban, rural and urban-rural gminas were also observed.

\section{Conclusions}

The ISO 9001 QMS is the one of the dominant approaches in Poland for improving the performance of LGUs. Previous studies and the literature review allowed us to distinguish the factors that have been defined as being important to the organisational resource capacity and that are needed for ISO 9001 QMS implementation. Our analysis shows that the significance of the particular factors of organisational capacity are different for the different types of gminas and poviats.

Human resources differentiate only the gminas (urban, rural and urban-rural) that have implemented the ISO 9001 QMS from those who do not have experience with this solution. The hypothesis that the factor skills will affect the willingness to use the ISO 9001 QMS in the future was only partially confirmed. It turns out that this statement is true only in case of urban 
gminas. The money factor was built by using the variables "income per inhabitant", "expenditures per inhabitant" and "share of investment expenditures". Not all variables that were part of this factor affected gminas and poviats in the same way. In the case of urban gminas, both income and expenditures per inhabitant statistically significantly differentiated those with the ISO 9001 QMS from those without it. The share of investment expenditures statistically significantly differentiated only the groups of rural gminas. Additionally, in the case of poviats, both income and expenditures per inhabitant are variables that differed for those who have experience with the ISO 9001 QMS and express their willingness to use the QMS in the future. The hypothesis that the complexity of the structure will be a determining factor in the ISO 9001 QMS implementation of urban gminas and poviats was only partially confirmed.

It should be stated that the implementation of the ISO 9001 QMS in Polish LGUs depended on organisational resource capacity factors, which, in the case of different LGUs, do not equally affect the implementation of the ISO 9001 QMS or the desire to apply it in the future, the type of assistance that was used in the ISO 9001 QMS implementation or the assessment of the effects of implementation. This variability may be caused by the specificity of Polish LGUs. It seems that particular types of local administrations have specific actions and characteristics, which cause different factors of the organisational capacity to be important to them during the implementation of the QMS.

In sum, having sufficient resources and the ability to access to them are necessary conditions for introducing the certified QMS into organisations. Otherwise, the implementation of the ISO 9001 QMS could not take place in Polish LGUs, especially in rural gminas. For urban gminas, another issue appears, which is the complexity of managing larger organisations. With respect to QMS maintenance, soft skills appear as an additional significant factor. Therefore, it could be concluded that the organisational capacity components play different roles depending on the organisation's size and resourcefulness and on ISO 9001 QMS (implementation and maintenance) use. The change of the required resources in connection with the implementation of ISO 9001 and the organisation's size can be visualised (Fig. 3).

Our work, as theory-testing research, weakens common assumptions about the significance of resource availability since it was showed that not all factors are equally important. As it was demonstrated, only a few conditions showed statistically significant differences between the analysed groups. Our study develops the resource-based theory for implementing management systems by assessing and providing the

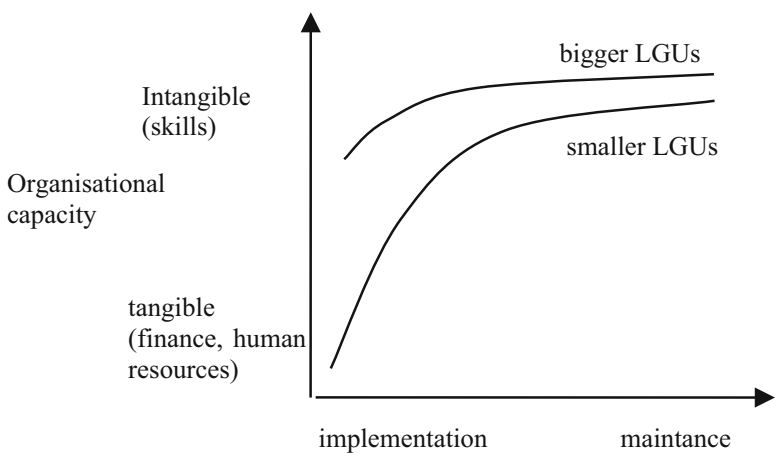

ISO 9001 QMS

Fig. 3 Resource-dependency and the ISO 9001 QMS implementation in LGUs. Source: own elaboration 
constraints and facilitators. Moreover, this study contributes to change management theory in local government by analysing the resource requisition for modernisation using managerial solutions, which are represented here by the ISO 9001 QMS. Particularly, our paper demonstrates that the significance of resources varies across the different types of LGUs. We demonstrate it by showing a resource-dependency and the ISO 9001 QMS implementation in LGUs. This paper brings value to mentioned theories by pointing out that bigger and smaller LGU's requires different type of resources during introduction and maintenance of QMS.

It should be emphasised that the conducted research has limitations. First, it can be not determined if opinions regarding the ISO 9001 QMS depend on the time of its use. It should also be added that the respondents in the surveys were LGU secretaries. Often, they are responsible for the implementation of the solution, which could affect the answers.

As for directions of future research, it would be interesting for both theory and practice to investigate other components of LGUs' organisational capacity, such as those that are more oriented to intangible resources.

\section{Compliance with Ethical Standards}

Conflicts of interest The publication is co-financed from the funds allocated by the Ministry of Science and Higher Education of the Republic of Poland to the Cracow University of Economics.

Open Access This article is licensed under a Creative Commons Attribution 4.0 International License, which permits use, sharing, adaptation, distribution and reproduction in any medium or format, as long as you give appropriate credit to the original author(s) and the source, provide a link to the Creative Commons licence, and indicate if changes were made. The images or other third party material in this article are included in the article's Creative Commons licence, unless indicated otherwise in a credit line to the material. If material is not included in the article's Creative Commons licence and your intended use is not permitted by statutory regulation or exceeds the permitted use, you will need to obtain permission directly from the copyright holder. To view a copy of this licence, visit http://creativecommons.org/licenses/by/4.0/.

\section{References}

Almeida, D., Pradhan, N., \& Muniz Jr., J. (2018). Assessment of ISO 9001:2015 implementation factors based on AHP: Case study in Brazilian automotive sector. International Journal of Quality \& Reliability Management, 35(7), 1343-1359. https://doi.org/10.1108/IJQRM-12-2016-0228.

Björk, L., Szücs, S., \& Härenstam, A. (2014). Measuring capacity to perform across local government services - Managers' perceptions. International Journal of Public Sector Management, 27(1), 26-38. https://doi. org/10.1108/IJPSM-09-2012-0115.

Bos, J. J., \& Brown, R. R. (2014). Assessing organisational capacity for transition policy programs. Technological Forecasting and Social Change, 86, 188-206. https://doi.org/10.1016/j. techfore.2013.09.012.

Boyne, G. A. (2003). Sources of public service improvement: A critical review and research agenda. Journal of Public Administration Research and Theory, 13(3), 367-394. https://doi.org/10.1093/jopart/mug027.

Briscoe, J. A., Fawcett, S. E., \& Todd, R. H. (2005). The implementation and impact of ISO 9000 among small manufacturing enterprises. Journal of Small Business Management, 43(3), 309-330. https://doi. org/10.1111/j.1540-627X.2005.00139.x.

Chiarini, A. (2016). Strategies for improving performance in the Italian local government organizations: Can ISO 9001 really help? International Journal of Quality \& Reliability Management, 33(3), 344-360. https://doi.org/10.1108/IJQRM-03-2014-0038.

Christensen, R. K., \& Gazley, B. (2008). Capacity for public administration: Analysis of meaning and measurement. Public Administration and Development, 28(4), 265-279. https://doi.org/10.1002/pad.500. 
Chu, P.-Y., Huang, C.-C., \& Wang, H.-J. (2001). ISO 9000 and public organizations in Taiwan: Organizational differences in implementation practices with organization size, unionization and service types. Public Organization Review, 1(4), 391-413.

Chu, P.-Y., \& Wang, H.-J. (2001). Benefits, critical process factors, and optimum strategies of successful ISO 9000 implementation in the public sector: An empirical examination of public sector Services in Taiwan. Public Performance \& Management Review, 25(1), 105-121. https://doi.org/10.1080/15309576.2001.11643648.

Ćwiklicki, M., Pilch, K., \& Żabiński, M. (2019). ISO 9001 quality management systems in local government institutions in Poland: Past, present and future. International Review of Administrative Sciences, 002085231881528. doi:https://doi.org/10.1177/0020852318815280.

Ingraham, P. W. (2005). Performance: Promises to keep and miles to go. Public Administration Review, 65(4), 390-395. https://doi.org/10.1111/j.1540-6210.2005.00466.x.

Judge, W. Q., \& Elenkov, D. (2005). Organizational capacity for change and environmental performance: An empirical assessment of Bulgarian firms. Journal of Business Research, 58(7), 893-901. https://doi. org/10.1016/j.jbusres.2004.01.009.

Leung, H. K. N., Chan, K. C. C., \& Lee, T. Y. (1999). Costs and benefits of ISO 9000 series: A practical study. International Journal of Quality \& Reliability Management, 16(7), 675-691. https://doi. org/10.1108/02656719910283362.

McGuire, M., \& Silvia, C. (2010). The effect of problem severity, managerial and organizational capacity, and agency structure on intergovernmental collaboration: Evidence from local emergency management. Public Administration Review, 70(2), 279-288. https://doi.org/10.1111/j.1540-6210.2010.02134.x.

Montesinos, V., \& Brusca, I. (2009). Towards performance, quality and environmental Management in Local Government: The case of Spain. Local Government Studies, 35(2), 197-212. https://doi.org/10.1080 /03003930902742971.

OECD. (2018). OECD rural policy reviews: Poland 2018. Paris: OECD Publishing.

Psomas, E. L., Fotopoulos, C. V., \& Kafetzopoulos, D. P. (2010). Critical factors for effective implementation of ISO 9001 in SME service companies. Managing Service Quality: An International Journal, 20(5), 440-457. https://doi.org/10.1108/09604521011073731.

Sampaio, P., Saraiva, P., \& Guimarães Rodrigues, A. (2009). ISO 9001 certification research: Questions, answers and approaches. International Journal of Quality \& Reliability Management, 26(1), 38-58. https://doi.org/10.1108/02656710910924161.

Saner, R. (2002). Quality Assurance for Public Administration: A consensus building vehicle. Public Organization Review, 2(4), 404-417.

Sfakianaki, E., \& Kakouris, A. P. (2018). Obstacles to ISO 9001 certification in SMEs. Total Quality Management \& Business Excellence, 1-21. https://doi.org/10.1080/14783363.2018.1490640.

Tan, E. (2019). Decentralization and capacity in public governance. In Decentralization and governance capacity (pp. 21-78). Cham: Springer International Publishing. https://doi.org/10.1007/978-3-030-02047-7_2.

To, W. M., Lee, P. K. C., \& Yu, B. T. W. (2011). ISO 9001:2000 implementation in the public sector: A survey in Macao SAR, the People's republic of China. The TQM Journal, 23(1), 59-72. https://doi. org/10.1108/17542731111097498.

Publisher's Note Springer Nature remains neutral with regard to jurisdictional claims in published maps and institutional affiliations.

Marek Ćwiklicki is a Associate Professor of Business Studies and Public Management and Head of Department for Management of Public Organisations at the Cracow University of Economics in Poland. He researches, writes, and lectures on organisation theory, business research methodology, and public management.

Barbara Pawelek is an Associate Professor in the Department of Statistics at the Cracow University of Economics (Poland). She has done extensive research on data analysis, classification methods, data mining, modeling and forecasting of socio-economic phenomena, prediction of company bankruptcy.

Kamila Pilch is a research assistant in the Deparment for Management of Public Organisations at the Cracow University of Economics (Poland). She lectures on public relations, economy and public administration and information management. Her research interests include methodology of marketing and social research, place branding and analysis of public policies. 